\title{
Investigation of Anticancer Agents from the Bark of Gyrinops versteegii (GILG.) Domke from Lombok Island
}

\author{
SURYA HADI ${ }^{1 *}$, DIAN LESTARI ${ }^{1}$, NI KOMANG TRI DHARMAYANI ${ }^{1}$, \\ BAIQ DESY RATNASARI ${ }^{2}$, M ITO ${ }^{3}$, I YAMADA ${ }^{4}$ and TRI MULYANINGSIH ${ }^{5}$ 2Departmen of Pharmacy, Stikes Kusuma Bangsa Mataram-83126, Indonesia.
${ }^{3}$ Graduate School of Pharmaceutical Sciences, Kyoto University, Japan.
${ }^{4}$ Center for Southeast Asian Studies, Kyoto University, Kyoto-606-8501, Japan
${ }^{5}$ Department of Biology, The University of Mataram, Mataram-83126, Indonesia. \\ 'Department of Chemistry, The University of Mataram, Mataram-83126, Indonesia. \\ *Corresponding author E-mail: sur_hadi88@yahoo.com
}

http://dx.doi.org/10.13005/ojc/360605

(Received: October 20, 2020; Accepted: November 25, 2020)

\begin{abstract}
This study is part of a research collaboration between Kyoto University and The University of Mataram, aiming to identify and to utilize the agarwood plants, i.e., Gyrinops versteegii from Indonesia. The study, specifically, aims to discover anticancer agents from the bark of $G$. versteegii from Lombok Island of Indonesia. There were three provenances of $G$. versteegii observed, namely Soyun, Pantai, and Buaya. Based on the Brine Shrimp Lethality Test (BSLT), G. versteegii Buaya showed the highest cytotoxicity with $\mathrm{LC}_{50} 45,94 \mu \mathrm{g} / \mathrm{ml}$. Meanwhile, G. versteegii Soyun and Pantai have $\mathrm{LC}_{50} 75.86$ $\mu \mathrm{g} / \mathrm{mL}$ and $56.36 \mu \mathrm{g} / \mathrm{mL}$ respectively. A phytochemical study showed that the methanol extract of G. versteegii Buaya containing compounds from the group of alkaloid, flavonoid, steroid, triterpenoid, and saponin. The methanol extracts fractionated using Vacuum Liquid Chromatography into 10 fractions (F1-F10) and then retested BSLT. Among the fractions, F2 showed the best potency as an anticancer with $\mathrm{LC}_{50} 64,12 \mu \mathrm{g} / \mathrm{mL}$. Based on the GC-MS analysis, the cytotoxicity from both methanol extract and F2 is predicted to be influenced by the same compounds, namely, 1,4-Benzenediol, 2-methyl, Pyridoxylamine, 2,3-Dimethylhydroquionone, Tetramethyl-p-benzoquinone and Benzofuran. Overall the bark of $G$. versteegii from Lombok Island has great potency as an anticancer.
\end{abstract}

Keywords: Agarwood, Anticancer, Gyrinops versteegii, Lombok Island, Provenance.

\section{INTRODUCTION}

In an attempt to preserve the germplasm of agarwood, especially in the West Nusa Tenggara, a collection and an identification of agarwood plant is continuously conducted. Gyrinops versteegii (Gilg.) Domke is one of the agarwood species found in Nusa
Tenggara, specifically Lombok Island. This species is classified as superior agarwood that produces highquality resin. As a result, the demand for $G$. versteegii is increasing by the year. Thus, exploration and plantation of this species are vigorously conducted, specifically in Lombok's forest. ${ }^{1-3}$ G. versteegii in West Lombok is found in five provenances, namely

This is an Open Access article licensed under a Creative Commons license: Attribution 4.0 International (CC- BY). Published by Oriental Scientific Publishing Company @ 2018

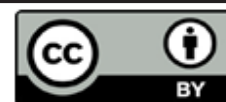


"G. versteegii Buaya"; "G. versteegii Soyun"; "G. versteegii Pantal"; "G. versteegii Madu"; and "G. versteegii Beringin". 2,4

The aromatic resin of the agarwood is the most attractive part of the plant. It is processed as fragrant oil to produce perfume and medicine. The other parts of the plant such as the leaves, the barks, the fruits, and the flowers are not fully recovered industrially and scientifically. Nevertheless, they possess many valuable bioactivities to maintain health and to treat some ailments like cirrhosis, tumor and cancer. ${ }^{4}$ However a clinical study of those bioactivities has not been conducted widely, especially in Lombok Island. Therefore the total utilization of agarwood parts, especially the barks, not only the resin part, is eagerly needed.

Hadi et al., ${ }^{5}$ pronounced the major compound of $G$. versteegii bark a flavonoid. Flavonoid is well known to possess an anti-cancer activity. However the study has not been conducted widely. Generally, agarwood plants have good bioactivity as anti-cancer. Another agarwood species like Aquilaria malaccensis was reported to inhibit the proliferation of HCT116 with $\mathrm{IC}_{50} 4 \mu \mathrm{g} / \mathrm{mL} .{ }^{6}$ Besides, it also effective against lymphocytic leukemia cell P-388 with ED50 0,35 $\mu \mathrm{g} / \mathrm{mL} .^{7}$ Further study found that the secondary metabolites, 2-(2-phenylethyl) chromones, that was isolated from agarwood was showing anti-cancer activity with $\mathrm{IC}_{50} 14,6 \mu \mathrm{g} / \mathrm{mL}$ against SGC-7901. ${ }^{8}$ Thus, theoretically, the species of Gyrinops has the same potential as the Aquilaria's as an anti-cancer agent.

This research is designed to investigate the compound that is responsible for the anti-cancer in the bark of $G$. versteegii of Lombok Island from three provenances (G. versteegii Soyun, G. versteegii Pantai and G. versteegii Buaya) using Brine Shrimp Lethality Test (BSLT). Furthermore, the chemical compound in the barks was identified based on Gas Chromatography-Mass Spectrometry (GC-MS).

\section{MATERIAL AND METHODS}

\section{Preparation}

The bark samples were obtained from three provenances of G. versteegii (Soyun, Pantai, and Buaya) from various places of Lombok Island, namely "Dusun Kerujuk, Pemenang Barat Village" and "the forest of Pusuk Lestari, Lembah Sari village".

\section{Maceration and Separation}

$500 \mathrm{~g}$ of each samples (Soyun, Pantai, and Buaya) were dried then mashed finely into powder before macerated with methanol for $3 \times 24$ hours. The crude extracts of each samples then tested using the Brine Shrimp Lethality Test (BSLT) to identify their toxicity level. The most toxic extract then chosen for the next step of separation using a vacuum liquid chromatography (VLC) technique. The stationary phase was silica gel GF60, while the mobile phase was $\mathrm{n}$-heksane, DCM, methanol, etylacetate and aceton. The fractions that have the same retention factor (RF) in thin layer chromatography (KLT) were combined then were retested using BSLT to detect the most toxic fraction. Finally, the chemical compounds in the most poisonous fraction were identified applying gas chromatography-mass spectrometry (GC-MS).

\section{Phytochemical test}

Phytochemical test was conducted to analyze the compound group in the extracts qualitatively. The most toxic provenance and the combinations of the fractions from VLC was tested alkaloid, flavonoid, steroid, triterpenoid, and saponin using respective reagent.

\section{Toxicity test using BSLT}

The toxicity test was conducted using BSLT. First of all, stock solutions were made by adding 50 $\mathrm{mg}$ of samples into $5 \mathrm{~mL}$ of DMSO. The stock solutions then diluted into various concentrations, namely 10 ppm, 100 ppm, and 1000 ppm (Test Solutions). $5 \mathrm{~mL}$ of each test solutions were put into a tube, then added with ten (10) Artemia salina L. Larvae. The toxicity level was analyzed by counting larvae mortality after observed for 24 hours. The mortality percentage was counted using Abbot formula. ${ }^{9}$

$\%$ Mortality $=\frac{(\text { sample mortality }- \text { control } \% \text { mortality })}{(100-\text { control } \% \text { mortality })}$

The mortality percentage then conversed into $\mathrm{LC}_{50}$ using statistical analysis (Probit and regression analysis). ${ }^{10}$

$y=a x+b$

\section{GC-MS Analysis}

The GC-MS type is QP2010S SHIDMADZU. 
In the analysis, helium was used as the carrier gas. The column type was Rtx 5 semi-polar with $30 \mathrm{~m}$ long, $0.25 \mathrm{~mm}$ diameter and $0.25 \mu \mathrm{m}$ film thickness. Helium was used as the gas carrier with flow rate $30 \mathrm{~mL} /$ minute. The molecular mass range of ions was identified at $35-500 \mathrm{~m} / \mathrm{z}$. the temperature program: the injection temperature was set to $260^{\circ} \mathrm{C}$ with initial column started at $40^{\circ} \mathrm{C}$ for $5 \mathrm{~min}$ and programmed to increase $30^{\circ} \mathrm{C}$ per min until it reached $260^{\circ} \mathrm{C}$ for 7 minutes.

\section{RESULT AND DISCUSSION}

Toxicity test

Tabel 1: Toxicity result of the methanol extract of the $G$. versteegii bark from the three provenance

\begin{tabular}{|c|c|c|c|c|c|c|c|}
\hline \multirow[t]{2}{*}{ Provenance } & \multirow[t]{2}{*}{ Concentration (ppm) } & \multirow[t]{2}{*}{ Log concentration } & \multicolumn{3}{|c|}{$\sum$ larvae mortality rate after $24 \mathrm{~h}$} & \multirow[t]{2}{*}{ Mortality (\%) } & \multirow{2}{*}{$\begin{array}{r}\mathrm{LC}_{50} \\
(\mu \mathrm{g} / \mathrm{mL})\end{array}$} \\
\hline & & & 1 & 2 & 3 & & \\
\hline \multirow[t]{3}{*}{ Soyun } & 1000 & 3 & 10 & 10 & 10 & 100 & 75,86 \\
\hline & 100 & 2 & 3 & 3 & 2 & 27 & \\
\hline & 10 & 1 & 1 & 2 & 1 & 13 & \\
\hline \multirow[t]{3}{*}{ Buaya } & 1000 & 3 & 10 & 10 & 10 & 100 & 45,94 \\
\hline & 100 & 2 & 4 & 5 & 3 & 40 & \\
\hline & 10 & 1 & 3 & 2 & 3 & 27 & \\
\hline \multirow[t]{3}{*}{ Pantai } & 1000 & 3 & 10 & 10 & 10 & 100 & 56,36 \\
\hline & 100 & 2 & 4 & 5 & 4 & 43 & \\
\hline & 10 & 1 & 2 & 0 & 3 & 17 & \\
\hline Standard & - & & & & & & \\
\hline Sea Water & & 0 & 0 & 0 & 0 & 0 & 0 \\
\hline DMSO & - & 0 & 0 & 0 & 0 & 0 & 0 \\
\hline
\end{tabular}

Tabel 2: Toxicity result of the G. versteegii Buaya fractions

\begin{tabular}{|c|c|c|c|c|c|c|c|}
\hline \multirow[t]{2}{*}{ Fractions } & \multirow[t]{2}{*}{ Concentration (ppm) } & \multirow[t]{2}{*}{ Log concentration } & \multicolumn{3}{|c|}{$\sum$ larvae mortality rate after $24 \mathrm{~h}$} & \multirow[t]{2}{*}{ Mortality (\%) } & \multirow{2}{*}{$\begin{array}{c}\mathrm{LC}_{50} \\
(\mu \mathrm{g} / \mathrm{mL})\end{array}$} \\
\hline & & & 1 & 2 & 3 & & \\
\hline \multirow[t]{3}{*}{$1,3,6,7,10$} & 1000 & 3 & 10 & 10 & 10 & 100 & 489,89 \\
\hline & 100 & 2 & 0 & 0 & 0 & 0 & \\
\hline & 10 & 1 & 0 & 0 & 0 & 0 & \\
\hline \multirow[t]{3}{*}{2} & 1000 & 3 & 10 & 10 & 10 & 100 & 64,12 \\
\hline & 100 & 2 & 9 & 7 & 7 & 77 & \\
\hline & 10 & 1 & 1 & 0 & 0 & 3 & \\
\hline \multirow[t]{3}{*}{4} & 1000 & 3 & 10 & 10 & 10 & 100 & 116,81 \\
\hline & 100 & 2 & 0 & 2 & 1 & 10 & \\
\hline & 10 & 1 & 1 & 1 & 0 & 7 & \\
\hline \multirow[t]{3}{*}{5,9} & 1000 & 3 & 10 & 10 & 10 & 100 & 254,02 \\
\hline & 100 & 2 & 1 & 0 & 0 & 3 & \\
\hline & 10 & 1 & 0 & 0 & 0 & 0 & \\
\hline \multirow[t]{3}{*}{8} & 1000 & 3 & 10 & 10 & 10 & 100 & 165,20 \\
\hline & 100 & 2 & 1 & 0 & 0 & 3 & \\
\hline & 10 & 1 & 1 & 0 & 0 & 3 & \\
\hline
\end{tabular}

Phytochemical test

Tabel 3: phytochemical study of the barks of G. versteegii Buaya

\begin{tabular}{clc}
\hline Compound class & Indication & Result \\
\hline Alkaloid & White Precipitation, the solution changes into green & + \\
& Brown precipitation, the solution changes into brownish oranges & + \\
Saponin & Foam appear for \pm 10 minutes & + \\
Flavonoid & The solution changes into blackish green & + \\
Steroid & Greenish blue ring appear in the solution & + \\
Terpene & The solution changes into brownish red & + \\
\hline
\end{tabular}


GC-MS Analysis

The methanol extract has 57 compounds

identified while the fraction-2 conveys 27 compounds.

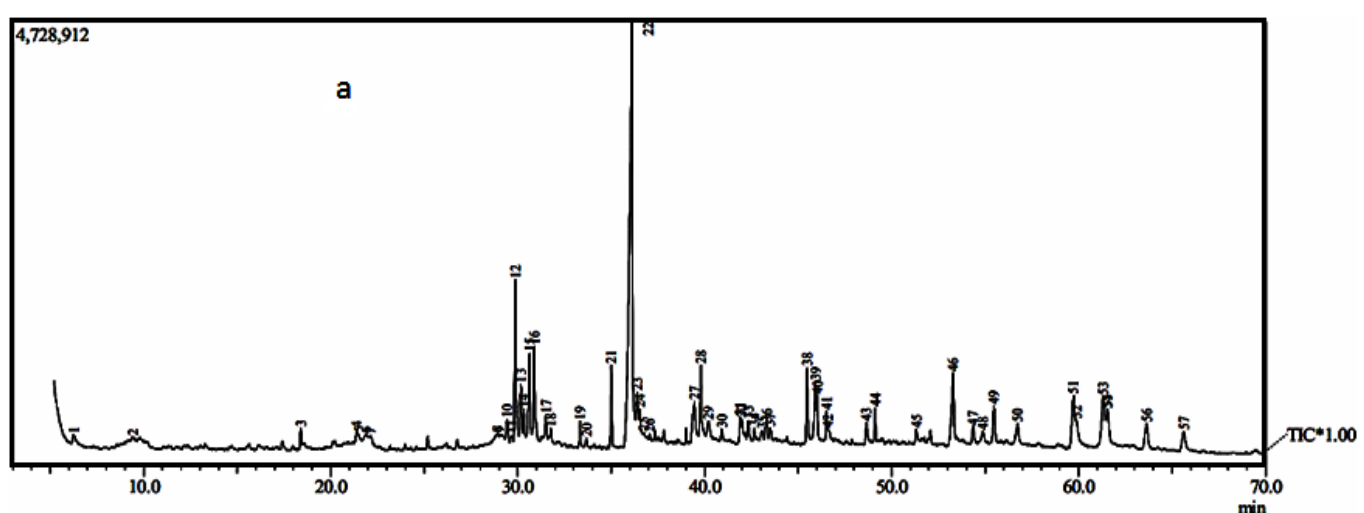

Chromatogram Emmy FJ Ektrk Me Klt Btg Gaharu C:\GCMS solution\Data Project Rtx 5 MS 2019\Emmy Me Klt Btg Gaharu. qgd

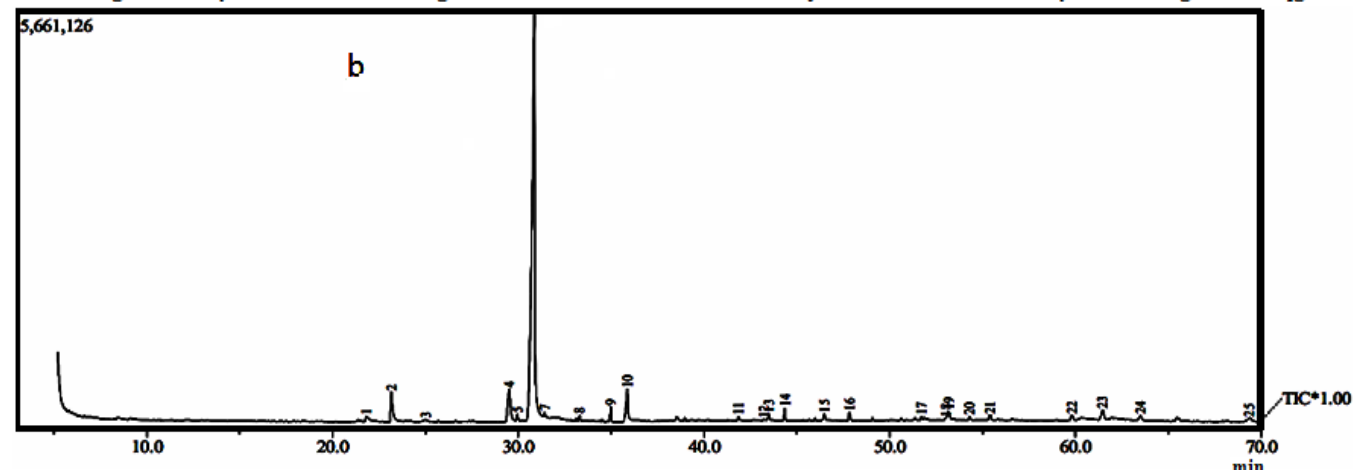

Fig. 1. GC-MS chromatogram of the G. versteegii Buaya extract Methanol extract b. fraction 2

DISCUSSION

\section{Toxicity test}

The methanol extract of $G$. versteegii Soyun, G. versteegii Buaya, and G. versteegii Pantai was evaluated for the toxicity activity against Brine Shrimp Larvae. The macerate was diluted into 1000 , 100 and $10 \mathrm{ppm}$ and the result of the test is provided in Table 1.

Based on Table 1, the G. versteegii Buaya variety has shown the highest cytotoxicity with $\mathrm{LC}_{50}$ $45,94 \mu \mathrm{g} / \mathrm{m}$. A compound is classified as toxic if it has $L_{50}<1000 \mu \mathrm{g} / \mathrm{mL}$ according to Meyer et al., ${ }^{9}$. Thus, G. versteegii Buaya, as the most poisonous variety, was chosen for the next steps that are phytochemical test and compound separation using liquid vacuum chromatography. The phytochemical test result is displayed in Table 3. Generally, the bark of $G$. versteegii Buaya is containing alkaloid, saponin, flavonoid, steroid, and terpene. Alkaloid and flavonoid have been known for their anti-cancer and anti-tumor properties. ${ }^{11}$ Hence, a further separation of the methanol extract was conducted.

The separation of the G. versteegii Buaya extract with liquid vacuum chromatography yielding ten fractions (F1-F10) that were obtained by adding the solution polarity with the eluen of $n$-hexane: ethyl acetate. The ratio were $10: 0 ; 9: 1 ; 7: 3 ; 6: 4 ; 5: 5 ; 3: 7 ; 1: 9$ respectively. These fractions then retested their toxicity level using BSLT and the result is shown in Table 2.

Based on Tabel 2, F2 has the highest toxicity activity against the Artemia salina $L$. larvae with $\mathrm{LC}_{50} 64 .{ }^{12} \mu \mathrm{g} / \mathrm{mL}$. According to Hamidi et al., ${ }^{10}$ this result is classified as forceful toxicity. If the LC $_{50}$ is around $500-100 \mu \mathrm{g} / \mathrm{mL}$, it is classified as weak, while $100-500 \mu \mathrm{g} / \mathrm{mL}$ is moderate and $0-100 \mu \mathrm{g} / \mathrm{mL}$ is strong. Nevertheless, the toxicity of F2 is weaker compared to the crude methanol extract of the $G$. versteegii Buaya, which have $\mathrm{LC}_{50} 45.94 \mu \mathrm{g} / \mathrm{mL}$. The strong-toxicity activity is associated with the number of metabolites in the extract. Overall, these results reveal a potency of the G. versteegii "Buaya" as a 
new anti-cancer agent. The chemical compound in the methanol extract and the F2 was identified based on GC-MS.

\section{GC-MS Analysis}

According to the literature review, overall, five anti-cancer compounds are detected in both methanol extract and F2. Those compounds are 1,4-Benzenediol,2-methyl (1), Pyridoxylamine (2), 2,3-Dimethylhydroquionone (3), Tetramethyl-pbenzoquinone (4) and Benzofuran (5). The abundance percentage in the extracts is displayed in Table 4.

Tabel 4: Anticancer compounds in the methanol extract and the fraction 2 of G. versteegii Buaya

\begin{tabular}{llcc}
\hline No & Compound & \% Area in $\mathrm{MeOH}$ extract & \% Area in Fraction 2 \\
\hline 1 & 1,4-Benzenediol,2-methyl (1) & 1.23 & 0.68 \\
2 & Pyridoxylamine (2) & 1.28 & 5.64 \\
3 & 2,3-Dimethylhydroquionone (3) & 2.37 & 3.79 \\
4 & Tetramethyl-p-benzoquinone (4) & 3.67 & 72.25 \\
5 & Benzofuran (5) & 3.30 & 1.42 \\
\hline
\end{tabular}

Tetramethyl-p-benzoquinone (4) or known as duroquinone is a part of benzoquinone compound. It is detected as the most abundance compound in both methanol extract and F2. Benzoquinone has been proved to have potential in treating breast cancer. The compound has effectively inhibiting the proliferation of estrogen receptor-positive MCF-7 cells through the NF$\kappa \mathrm{B}$ pathway via estrogen receptor signaling. ${ }^{12}$ Other quinone compounds also detected in the agarwood barks extracts as hydroquinone group, which are 1,4-Benzenediol,2-methyl (1) and 2,3-Dimethylhydroquionone (3). They are reported to successfully induce the death cell of A431 epidermal cell lines, SYF (Src, Yes, and Fyn), B16F10 and MDA-MB-231-cells that are implicated as key regulators of ligand-induced cellular responses including proliferation, survival, adhesion and migration. Furthermore, the process of the cell cancer inducement is rated to be safe and efficient without adverse effect. ${ }^{13}$

Pyridoxylamine (2), commercially known as vitamin B6, is a primary metabolite that is important for metabolism. It has a great record of its anti-cancer activity. It is reported that pyridoxylamine has suppressed cell proliferation of B16 and B16F10 murine melanoma cells and M21-HPB human melanoma cells. ${ }^{14}$ Benzofuran (5) and its derivatives like 5-Methyl-benzofurazan (6) have reported to effectively kill cancer cells line like lipoma, Hella, ovarian cancer and leukemia cells by inhibiting the cell proliferation. In addition, benzofuran and its derivative also have antitumor activity against MCF-7 dan PC-3. ${ }^{15-19}$<smiles>Cc1c(O)ccc(O)c1Cl</smiles><smiles>Cc1ncc(CO)c(CN)c1O</smiles><smiles>Cc1c(O)ccc(O)c1C</smiles><smiles>CC1=C(C)C(=O)C(C)=C(C)C1=O</smiles><smiles>c1ccc2occc2c1</smiles>

(4)

Fig. 2. Anticancer compounds in the methanol extract and the $\mathrm{F} 2$ of $G$. versteegii Buaya

Other compounds that are detected in the methanol extract of $G$. versteegii Buaya are $\alpha$-Caryophyllene (6) $\beta$-Santalol (7). $\alpha$-Caryophyllene (6), known as humulene is sesquiterpenes that is found in the essential oil. This compound is one of the responsible compounds for the aromatic scent. Furthermore, this compound is also known for its anti-cancer activity. According to Ambroz et al., ${ }^{20}$, 21 Humulene is an effective treatment for intestinal, ovarian and lymphoblast cancer by inhibiting the proliferation process and oxidating effect.

$\beta$-Santalol is one of the substantial compounds in sandalwood essential oil (SEO). An exposure of SEO (2-8 $\mu \mathrm{g} / \mathrm{mL}$ for $24 \mathrm{~h}$ ) is capable of breaking the single- and double-strand DNA in the MCF-7 cells, a human breast cell line. This genotoxic activity is contributed by the presence of $\beta$-Santalol, along with $\alpha$-Santalol. ${ }^{22}$ 


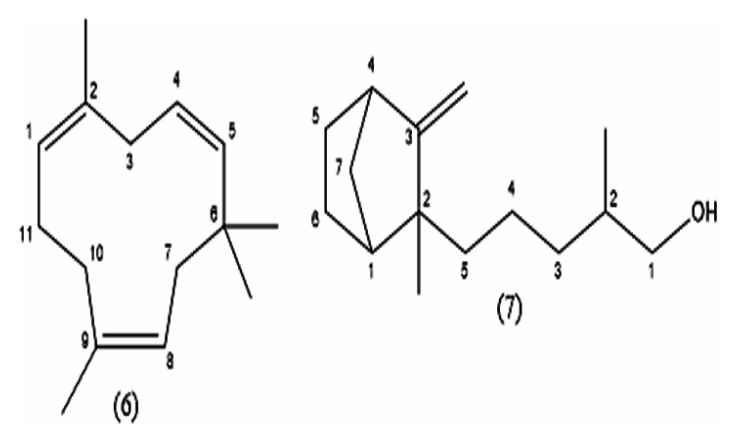

Fig. 3. Other compounds that are detected in the barks of methanol extract of G. versteegii Buaya

\section{CONCLUSION}

Among $G$. versteegii provenances that are found in the Lombok Island, G. versteegii Buaya has the most toxic effect on the brine shrimp larvae that consequently makes it as the most potential provenance to be developed as anticancer drugs.
Specifically, the methanol extract was more active in inhibiting larvae reproduction. The cytotoxicity from both methanol extract and F2 is predicted to be influenced by the same compounds, namely, 1,4-Benzenediol,2methyl, pyridoxylamine, 2,3-Dimethylhydroquionone, Tetramethyl-p-benzoquinone, and benzofuran. Moreover, the methanol extract has two additional compounds ( $\alpha$-Caryophyllene and $\beta$-Santalol) that strengthen its cytotoxic activity.

\section{ACKNOWLEDGEMENT}

We would like to give sincere gratitude to MENRISTEK (Ministry of Research and Technology) of Indonesia (contract number of research grant: 735/ UN18.L1/PP/2018) for funding this research.

\section{Conflict of Interest}

The authors declare that this research has no conflict of interest.

\section{REFERENCES}

1. Mulyaningsih, T.; Yamada, I.Natural resource management and socio-economic transformation under the decentralization in Indonesia: Toward Sulawesi area studies. 2007, 365-372.

2. Mulyaningsih, T.; Marsono, D.; Sumardi, S.; Yamada, I. Jurnal Penelitian Hutan dan Konservasi Alam., 2017, 14(1), 57-67.

3. Mulyaningsih, T.; Marsono, D.; Sumardi; Yamada, I. Ecology, Environment and Conservation Paper., 2017, 23, 723-729.

4. Setyaningrum, H. D.; Saparinto, C. Penebar Swadaya Grup., 2014.

5. Hadi, S.; Muliasari, H.; Sukma, N. S.; Ratnaningsih, P. E. W.Proceeding of the $2^{\text {th }}$ International Seminar on Chemistry, Jatinangor., 2011, 79-82.

6. Ibrahim, A. H.; Al-Rawi, S.S.; Majid, A. M.S. A.; Rahman, N. N. A.; Abo-Salah, K. M.; Ab Kadir, M. O. Proc. Food Scien., 2011, 1, 1953-1959.

7. Gunasekera, S. P.; Faircloth, G.T. The Journal of Organic Chemistry., 1990, 55(25), 6223-6225.

8. Liu, J.; Wu, J.; Zhao, Y. X.; Deng, Y. Y.; Mei, W. L.; Dai, H. F. Chinese Chemical Letters., 2008, 19(8), 934-936.

9. Meyer, B. N.; Ferrigni, N. R.; Putnam, J. E.; Jacobsen, L. B.; Nichols, D. E. j.; McLaughlin, J. L. Planta medica., 1982, 45(05), 31-34.

10. Hamidi, M. R.; Jovanova, B.; Panovska, T. K. Maced pharm bull., 2014, 60(1), 9-18.

11. Bhavana, V.; Sudharshan, S. J. S.; Madhu,
D. Anticancer plants: clinical trials and nanotechnology, Springer., 2017, 51-104.

12. Zheng, L.; Cai, Y.; Zhou, L.; Huang, P.; Ren, X.; Zuo, A.; Meng, X.; Xu, M.; Liao, X. International J. of Molecu. Medicn., 2017, 39(1), 39-46.

13. Byeon, S. E.; Yi, Y.-S.; Lee, J.;Yang, W. S.; Kim, J. H.; Kim, J.; Hong, S.; Kim, J.-H.; Cho, J.Y. Internal. J. of Molec. Scien., 2018, 19(3), 903.

14. Matsuo, T.; Sadzuka, Y. Anticancer research., 2019, 39(7), 3429-3432.

15. Napiórkowska, M.; Cieslak, M.; KaomierczakBaranska, J.; Królewska-Golinska, K.; Nawrot, B. Molecules., 2019, 24(8), 1529.

16. Santha, S.; Dwivedi, C. Anticancer research., 2015, 35(6), 3137-3145.

17. Shah, C. P.; Kharkar, P. S. Journal of enzyme inhibition and medicinal chemistry., 2018, 33 (1), 972-977.

18. Xu, J.-P. CRC Press., 2016.

19. Coskun, D.; Tekin, S.; Sandal, S.; Coskun, M. F. Journal of Chemistry., 2016.

20. Ambrož, M.; Boušová, I.; Skarka, A.; Hanušová, V.; Králová, V.; Matoušková, P.; Szotáková, B.; Skálová, L. Molecules., 2015, 20(8), 15343-15358.

21. Ambrož, M.; Matoušková, P.; Skarka, A.; Zajdlová, M.; Žáková, K.; Skálová, L. Molecules., 2017, 22(6), 1021.

22. Ortiz, C.; Morales, L.; Sastre, M.; Haskins, W. E.; Matta, J. Evidence-Based Complementary and Alternative Medicine., 2016. 